\title{
Testosterone Replacement and Bone Mineral Density in Male Pituitary Tumor Patients
}

\author{
Min Jeong Lee ${ }^{1}$, Hyoung Kyu Ryu ${ }^{1}$, So-Yeon An², Ja Young Jeon ${ }^{1}$, Ji In Lee ${ }^{1}$, Yoon-Sok Chung ${ }^{1}$ \\ ${ }^{1}$ Department of Endocrinology and Metabolism, Ajou University School of Medicine, Suwon; ${ }^{2}$ Department of Internal \\ Medicine, Gyeonggi Provincial Medical Center Uijeongbu Hospital, Uijeongbu, Korea
}

Background: Hypopituitarism is associated with osteoporosis and osteopenia especially when hypogonadotropic hypogonadism is present. Despite hypopituitarism being an important cause of secondary osteoporosis, osteoporosis in patients receiving surgery for pituitary tumors in Korea has not been studied. In this study, we evaluated the effects of testosterone replacement therapy (TRT) on bone mineral density (BMD) in postoperative hypogonadal patients with pituitary tumors.

Methods: To examine the effect of TRT on BMD, we performed a retrospective observational study in 21 postoperative male patients who underwent pituitary tumor surgery between 2003 and 2012 at the Ajou University Hospital. Testosterone was replaced in postoperative hypogonadal patients by regular intramuscular injection, daily oral medication, or application of transdermal gel. BMD $\left(\mathrm{g} / \mathrm{cm}^{2}\right)$ measurements of central skeletal sites (lumbar spine, femoral neck, and total femur) were obtained using dual-energy X-ray absorptiometry (GE Lunar). For lumbar spine BMD, L1 to L4 values were chosen for analysis. Femur neck and total femur were also analyzed.

Results: During the follow-up period (mean, 56 months; range, 12 to 99 months) serum testosterone levels increased with the administration of TRT $(P=0.007)$. There was significant improvement $(4.56 \% \pm 9.81 \%)$ in the lumbar spine BMD compared to baseline BMD. There were no significant changes in the femur neck BMD or total femur BMD. We did not find any statistically significant relationships between changes in testosterone levels and BMD using Spearman correlation analysis.

Conclusion: Our results indicated that TRT used in the postoperative period for hypogonadal pituitary tumor surgery patients may have beneficial effects on the BMD of the spine.

Keywords: Osteoporosis; Bone density; Pituitary neoplasms; Hypogonadism; Testosterone; Male

\section{INTRODUCTION}

Male hypogonadism is characterized by abnormally low serum testosterone levels and typical symptoms that include sexual dysfunction, decreased muscle mass and strength, mood dysfunction, and decreased bone mineral density (BMD). Male hypogonadism is divided into categories according to whether

Received: 17 May 2013, Accepted: 11 October 2013

Corresponding author: Yoon-Sok Chung

Department of Endocrinology and Metabolism, Ajou University School of Medicine, 206 World cup-ro, Yeongtong-gu, Suwon 443-721, Korea

Tel: +82-31-219-5127, Fax: +82-31-219-4497, E-mail: yschung@ajou.ac.kr the pathology occurs at the testicular level (primary hypogonadism) or pituitary-hypothalamic level (secondary hypogonadism). Many symptoms of hypogonadism can be improved with testosterone replacement therapy (TRT) [1]. A low testosterone level gives rise to a decrease in BMD [2]. And such BMD changes in hypogonadal men could recover when they are treated with testosterone preparations. Testosterone treatments ef-

Copyright $\odot 2014$ Korean Endocrine Society

This is an Open Access article distributed under the terms of the Creative Commons Attribution Non-Commercial License (http://creativecommons.org/ licenses/by-nc/3.0/) which permits unrestricted non-commercial use, distribution, and reproduction in any medium, provided the original work is properly cited. 
fectively prevent bone loss in hypogonadal men, even at older ages $[3,4]$. While male hypogonadism has been previously under diagnosed, patient and physician awareness of this condition has increased in recent years and has resulted in greater numbers of patients being treated.

Although hypopituitarism is a well-known cause of secondary osteoporosis, those patients with pituitary tumors treated with surgery have not been studied in terms of osteoporosis in Korea [5]. There is little data on the beneficial effects of TRT for the postoperative hypogonadal patient with a pituitary tumor. Therefore, we investigated BMD changes in postoperative patients treated with TRT.

\section{METHODS}

We conducted a retrospective chart review of patients who visited Ajou University Hospital (Suwon, Korea) regularly after receiving surgery for pituitary tumors from January 2003 to December 2012. Participants aged 25 to 80 years with a basal serum testosterone level of less than $3.5 \mathrm{ng} / \mathrm{mL}$ were enrolled in this study. Although there is no established standard for the diagnosis of hypogonadism, 2006 recommendations by the Korean Society of Aging Male Research defined this condition as a serum total testosterone level less than $12 \mathrm{nmol} / \mathrm{L}$ (3.46 ng/ $\mathrm{mL})$ or a free testosterone value of less than $250 \mathrm{pmol} / \mathrm{L}(72$ $\mathrm{pg} / \mathrm{mL}$ ) [6]. We identified 22 male patients with baseline and follow-up measurements of BMD and serum testosterone levels. Testosterone was administered to 22 patients by regular intramuscular injection, daily oral medication, or application of transdermal gel. The form of TRT was selected by patient preference. Intramuscular testosterone was administered to patients included testosterone undecanoate (Nebido 1,000 mg/4 mL every 12 to 16 weeks; Bayer Pharma AG, Berlin, Germany) or testosterone enanthate (Jenasteron $250 \mathrm{mg} / 1 \mathrm{~mL}$ every 3 weeks; Bayer Pharma AG). Some patients received therapy with testosterone gel (Testo Gel 1\% 5 g, Hanmi Pharma, Seoul, Korea; or tostrex Gel 2\% 2.5 g, CJ CheilJedang Pharma, Seoul, Korea). The gel was applied once daily to clean, dry, and intact skin of the shoulders, upper arms, and/or abdomen, and allowed to dry for several minutes. Some patients also chose to receive oral testosterone undecanoate (andriol testocaps 80, 160, or $240 \mathrm{mg}$ /day; MSD, Whitehouse Station, NJ, USA). Regardless of the form of TRT, testosterone levels were assessed every 3 to 6 months with dose titrations to achieve a level of 3.5 to $5.5 \mathrm{ng} / \mathrm{mL}$. Thyroid hormones and glucocorticoid hormones were appropriately replaced by clinical practice guidelines if needed.

Height and body weight were measured by a standard method while the patient was wearing light clothes. Body mass index (BMI) was calculated as weight divided by height squared $\left(\mathrm{kg} / \mathrm{m}^{2}\right)$. BMD $\left(\mathrm{g} / \mathrm{cm}^{2}\right)$ measurements of central skeletal sites (lumbar spine, femoral neck, and total femur) were obtained using dual-energy X-ray absorptiometry (GE Lunar, Madison, WI, USA).

Blood samples were drawn from all patients for testosterone measurements. Serum testosterone levels were measured by radioimmunoassay. In the case of intramuscular testosterone injections, serum testosterone levels were measured after 1 week after the injections. All serum tests were obtained between AM 7:00 and AM 11:00 after 8 hours or more of fasting, and blood glucose, triglyceride, high density lipoprotein, cholesterol, blood urea nitrogen, and creatinine were measured. Values were expressed as mean \pm SD for descriptive statistics. Comparisons between baseline and follow-up parameters were made by Wilcoxon signed rank test. Because there was no placebo group or comparator group, all statistical comparisons were made in relation to baseline values. Raw data were plotted and Spearman correlation analysis was performed to assess changes in testosterone levels and BMD. Statistical data were analyzed using SPSS version 18 for Windows (IBM Co., Armonk, NY, USA). A $P<0.05$ was considered statistically significant.

\section{RESULTS}

We identified 22 male patients who underwent TRT after the removal of a pituitary tumor. Among these 22 patients, one patient with known chronic kidney disease (serum creatinine $2.7 \mathrm{mg} / \mathrm{dL}$ ) was excluded from the analysis. The summary of patients in this study are presented in Table 1 . The mean age and BMI was $44 \pm 14$ years and $26.70 \pm 3.05 \mathrm{~kg} / \mathrm{m}^{2}$, respectively. Mean follow-up duration was 56 months (range, 12 to 99). Among the 21 subjects, 14 patients (66.7\%) received steroid hormone replacement and 10 patients (47.6\%) received thyroid hormone replacement. Pituitary tumor characteristics consisted of acromegaly (one case), Cushing disease (one case), prolactinoma (one case), and nonfunctioning pituitary tumors (18 cases). There were no prior clinical bone fractures and new clinical bone fractures during study period. Patients did not receive other treatments such as gamma-knife, radiotherapy, or chemotherapy during the follow-up period. Data for initial age, height, body weight, BMI, serum testosterone, calcium, phosphate, fasting glucose, and creatinine are listed in Ta- 
Table 1. Summary of Patients in This Study (Treated Group, 21 Patients)

\begin{tabular}{|c|c|c|c|c|c|c|c|c|c|c|c|}
\hline Patient & $\begin{array}{l}\text { Age at 1st } \\
\text { visit, yr }\end{array}$ & $\begin{array}{c}\text { Height, } \\
\mathrm{cm}\end{array}$ & $\begin{array}{l}\text { Weight, } \\
\text { kg }\end{array}$ & $\begin{array}{l}\mathrm{BMI}, \\
\mathrm{kg} / \mathrm{m}^{2}\end{array}$ & $\mathrm{DM}$ & HTN & $\begin{array}{c}\text { Thyroid hormone } \\
\text { replacement }\end{array}$ & $\begin{array}{l}\text { Steroid hormone } \\
\text { replacement }\end{array}$ & $\begin{array}{l}\text { Fracture } \\
\text { history }\end{array}$ & $\begin{array}{l}\text { Testosterone } \\
\text { replacement }\end{array}$ & $\begin{array}{l}\text { Follow-up } \\
\text { duration, mo }\end{array}$ \\
\hline 1 & 31 & 169.6 & 62.1 & 21.74 & $\mathrm{~N}$ & $\mathrm{Y}$ & None & Hydrocortisone $10 \mathrm{mg}$ & $\mathrm{N}$ & $\begin{array}{l}\text { Testosterone enanthate } \\
\mathrm{IM} \rightarrow \text { Tetosterone un- } \\
\text { decanoate IM }\end{array}$ & 70 \\
\hline 2 & 53 & 169.5 & 62.8 & 21.98 & Y & $\mathrm{N}$ & None & None & $\mathrm{N}$ & $\begin{array}{l}\text { Testosterone undecano- } \\
\text { ate po }\end{array}$ & 49 \\
\hline 3 & 57 & 160.5 & 66.8 & 25.77 & $\mathrm{~N}$ & $\mathrm{~N}$ & $\begin{array}{l}\text { Levothyroxine } \\
0.1 \mathrm{mg}\end{array}$ & Hydrocortisone $10 \mathrm{mg}$ & $\mathrm{N}$ & $\begin{array}{l}\text { Testosterone undecano- } \\
\text { ate po }\end{array}$ & 90 \\
\hline 4 & 46 & 165.4 & 73 & 26.81 & $\mathrm{~N}$ & $\mathrm{~N}$ & None & Hydrocortisone $5 \mathrm{mg}$ & $\mathrm{N}$ & $\begin{array}{l}\text { Testosterone enanthate } \\
\mathrm{IM} \rightarrow \text { Tetosterone un- } \\
\text { decanoate po }\end{array}$ & 54 \\
\hline 5 & 47 & 172.4 & 72.2 & 24.4 & $\mathrm{~N}$ & $\mathrm{~N}$ & $\begin{array}{l}\text { Levothyroxine } \\
0.1 \mathrm{mg}\end{array}$ & Hydrocortisone $20 \mathrm{mg}$ & $\mathrm{N}$ & $\begin{array}{l}\text { Testosterone enanthate } \\
\text { IM }\end{array}$ & 28 \\
\hline 6 & 53 & 181.4 & 106.5 & 32.5 & $\mathrm{~N}$ & $\mathrm{~N}$ & $\begin{array}{l}\text { Levothyroxine } \\
0.2 \mathrm{mg}\end{array}$ & Hydrocortisone $20 \mathrm{mg}$ & $\mathrm{N}$ & $\begin{array}{l}\text { Testosterone undecano- } \\
\text { ate po }\end{array}$ & 99 \\
\hline 7 & 35 & 172.1 & 87.6 & 29.6 & Y & Y & $\begin{array}{l}\text { Levothyroxine } \\
0.1 \mathrm{mg}\end{array}$ & None & $\mathrm{N}$ & $\begin{array}{l}\text { Testosterone undecano- } \\
\text { ate po }\end{array}$ & 68 \\
\hline 8 & 76 & 164 & 63 & 23.42 & Y & $\mathrm{N}$ & $\begin{array}{l}\text { Levothyroxine } \\
0.05 \mathrm{mg}\end{array}$ & Hydrocortisone $10 \mathrm{mg}$ & $\mathrm{N}$ & $\begin{array}{l}\text { Testosterone undecano- } \\
\text { ate po }\end{array}$ & 12 \\
\hline 9 & 26 & 164.7 & 80.1 & 29.7 & $\mathrm{~N}$ & $\mathrm{~N}$ & None & None & $\mathrm{N}$ & $\begin{array}{l}\text { Testosterone enanthate } \\
\mathrm{IM} \rightarrow \text { Tetosterone un- } \\
\text { decanoate IM }\end{array}$ & 83 \\
\hline 10 & 37 & 175 & 89.6 & 29.25 & $\mathrm{~N}$ & $\mathrm{~N}$ & None & None & $\mathrm{N}$ & Testosterone gel & 52 \\
\hline 11 & 35 & 174.2 & 84 & 31.65 & $\mathrm{~N}$ & $\mathrm{~N}$ & $\begin{array}{l}\text { Levothyroxine } \\
0.1 \mathrm{mg}\end{array}$ & Hydrocortisone $5 \mathrm{mg}$ & $\mathrm{N}$ & Testosterone gel & 69 \\
\hline 12 & 45 & 167.6 & 76.3 & 27.35 & $\mathrm{~N}$ & Y & None & Hydrocortisone $20 \mathrm{mg}$ & $\mathrm{N}$ & Testosterone gel & 68 \\
\hline 13 & 42 & 163.5 & 67.1 & 25.25 & $\mathrm{~N}$ & $\mathrm{~N}$ & None & None & $\mathrm{N}$ & $\begin{array}{l}\text { Tetosterone undecanoate } \\
\text { po } \rightarrow \text { Testoesterone gel }\end{array}$ & 28 \\
\hline 14 & 61 & 163.9 & 80.3 & 30.2 & Y & Y & None & None & $\mathrm{N}$ & $\begin{array}{l}\text { Testosterone undecano- } \\
\text { ate po }\end{array}$ & 51 \\
\hline 15 & 52 & 164.3 & 74.3 & 27.62 & $\mathrm{~N}$ & $\mathrm{~N}$ & None & None & $\mathrm{N}$ & Testosterone gel & 79 \\
\hline 16 & 31 & 165.9 & 70.5 & 25.89 & $\mathrm{~N}$ & $\mathrm{~N}$ & None & Hydrocortisone $20 \mathrm{mg}$ & $\mathrm{N}$ & Testosterone gel & 54 \\
\hline 17 & 25 & 176.4 & 74.4 & 24.01 & $\mathrm{~N}$ & $\mathrm{~N}$ & None & Hydrocortisone $20 \mathrm{mg}$ & $\mathrm{N}$ & $\begin{array}{l}\text { Testosterone undecano- } \\
\text { ate po }\end{array}$ & 42 \\
\hline 18 & 35 & 170.9 & 71.3 & 24.67 & $\mathrm{~N}$ & $\mathrm{~N}$ & $\begin{array}{l}\text { Levothyroxine } \\
0.1 \mathrm{mg}\end{array}$ & Hydrocortisone $10 \mathrm{mg}$ & $\mathrm{N}$ & Testosterone gel & 64 \\
\hline 19 & 26 & 170 & 83.4 & 28.85 & $\mathrm{~N}$ & $\mathrm{~N}$ & $\begin{array}{l}\text { Levothyroxine } \\
0.1 \mathrm{mg}\end{array}$ & Hydrocortisone $10 \mathrm{mg}$ & $\mathrm{N}$ & $\begin{array}{l}\text { Testosterone enanthate } \\
\text { IM }\end{array}$ & 56 \\
\hline 20 & 69 & 168.8 & 67.5 & 23.91 & $\mathrm{~N}$ & $\mathrm{Y}$ & $\begin{array}{l}\text { Levothyroxine } \\
0.1 \mathrm{mg}\end{array}$ & Hydrocortisone $20 \mathrm{mg}$ & $\mathrm{N}$ & $\begin{array}{l}\text { Testosterone undecano- } \\
\text { ate po }\end{array}$ & 18 \\
\hline 21 & 57 & 170.4 & 76 & 26.29 & $\mathrm{~N}$ & $\mathrm{Y}$ & $\begin{array}{l}\text { Levothyroxine } \\
0.1 \mathrm{mg}\end{array}$ & Hydrocortisone $10 \mathrm{mg}$ & $\mathrm{N}$ & $\begin{array}{l}\text { Testosterone undecano- } \\
\text { ate po }\end{array}$ & 41 \\
\hline
\end{tabular}

BMI, body mass index; DM, diabetes mellitus; HTN, hypertension; IM, intramuscular injection; po, per oral.

ble 2 .

Serum testosterone levels increased during the treatment period (Table 3). Similarly, BMD increased during TRT. There was a statistically significant improvement $(+4.56 \%$ from base- line) of the lumbar spine BMD (lumbar spine BMD change of $+0.0487 \pm 0.1046 \mathrm{~g} / \mathrm{cm}^{2} ; P=0.028$ ) (Table 4). However, there were no significant improvements seen in the femur neck or total femur BMD. 
Table 2. Baseline Characteristics of Study Subjects $(n=21)$

\begin{tabular}{lc}
\hline Characteristic & Value \\
\hline Age at diagnosis, yr & $44.7 \pm 14.4$ \\
Height, $\mathrm{cm}$ & $169.07 \pm 5.09$ \\
Weight, $\mathrm{kg}$ & $75.65 \pm 10.61$ \\
BMI, $\mathrm{kg} / \mathrm{m}^{2}$ & $26.70 \pm 3.05$ \\
Calcium, mg/dL & $9.20 \pm 0.55$ \\
Phosphate, $\mathrm{mg} / \mathrm{dL}$ & $3.73 \pm 0.83$ \\
Fasting glucose, $\mathrm{mg} / \mathrm{dL}$ & $96.76 \pm 17.76$ \\
Creatinine, $\mathrm{mg} / \mathrm{dL}$ & $0.98 \pm 0.16$ \\
Testosterone, ng/mL & $1.577 \pm 1.268$ \\
Spine BMD, T-score & $-0.96 \pm 1.27$ \\
Femur neck BMD, T-score & $-0.31 \pm 1.20$ \\
Femur total BMD, T-score & $0.17 \pm 1.22$ \\
\hline
\end{tabular}

Values are expressed as mean $\pm \mathrm{SD}$.

BMI, body mass index; BMD, bone mineral density.

Table 3. Changes in Serum Testosterone Levels $(n=21)$

\begin{tabular}{lcc}
\hline $\begin{array}{l}\text { Baseline testosterone, } \\
\mathrm{ng} / \mathrm{mL}\end{array}$ & $\begin{array}{r}\text { Follow-up testosterone, } \\
\mathrm{ng} / \mathrm{mL}\end{array}$ & $P$ value \\
\hline $1.577 \pm 1.268$ & $3.370 \pm 2.434$ & 0.007 \\
\hline
\end{tabular}

Values are expressed as mean $\pm \mathrm{SD}$. The mean observation time was 56 months. There was a significant increase in serum testosterone levels during testosterone replacement therapy $(P<0.05$ by Wilcoxon singed rank test).

Table 4. Comparison of Bone Mineral Density Changes $(n=21)$

\begin{tabular}{lccc}
\hline & BMD value, $\mathrm{g} / \mathrm{m}^{2}$ & $\Delta \mathrm{BMD}, \%$ & $P$ value $^{\mathrm{a}}$ \\
\hline Spine & & $4.56 \pm 9.81$ & 0.028 \\
BMD1 & $1.067 \pm 0.155$ & & \\
BMD2 & $1.116 \pm 0.177$ & & \\
Femur neck & & $-3.59 \pm 27.41$ & 0.677 \\
BMD1 & $0.908 \pm 0.148$ & & \\
BMD2 & $0.875 \pm 0.212$ & & 0.204 \\
Femur total & & $2.32 \pm 7.44$ & \\
BMD1 & $0.968 \pm 0.155$ & & \\
BMD2 & $0.990 \pm 0.166$ & & \\
\hline
\end{tabular}

Values are expressed as mean \pm SD. BMD1 refers to the first BMD measurement and BMD2 refers to the last BMD measurement during the observation period. The mean observation duration between BMD1 and BMD2 was 56 months.

BMD, bone mineral density.

${ }^{\mathrm{a} C}$ Comparisons between baseline BMD and follow-up BMD were analyzed by Wilcoxon signed rank test $(P<0.05$ was considered significant).
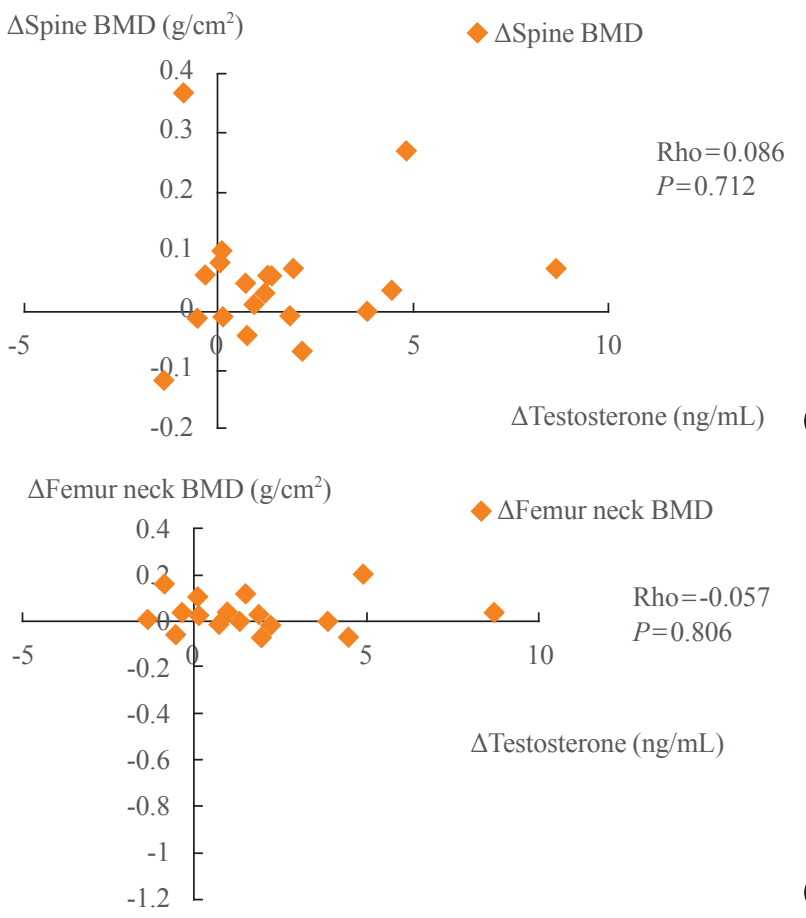

$\Delta$ Femur total BMD $\left(\mathrm{g} / \mathrm{cm}^{2}\right)$

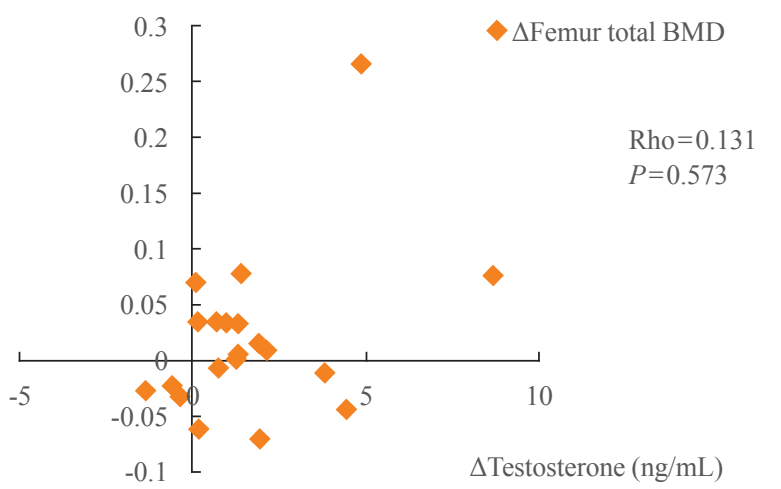

B

Fig. 1. (A-C) Correlation of testosterone level and bone mineral density (BMD) changes $(n=21)$.

Significant correlations were not observed between changes in testosterone levels and BMD by Spearman test $(n=21 ; \Delta$ spine, rho $=0.086, P=0.712 ; \Delta$ femur neck, rho $=-0.057, P=0.806 ; \Delta$ femur total, rho $=0.131, P=0.573$ ) (Fig. 1).

\section{DISCUSSION}

Decreases in BMD are frequently present in postoperative patients with pituitary tumors. Although the relationship between hypopituitarism and osteoporosis has been well studied, few studies are available for postoperative patients with pituitary tumor [5]. Our results demonstrated that TRT in postoperative hypogonadal patients is beneficial for improving BMD. 
Several results of previous studies showed that TRT resulted in significant improvements in BMD of the hip and lumbar spine in hypogonadal males, and a effective decline in bone turnover in the TRT group $[7,8]$. But many previous studies support that TRT reduces bone remodeling and increases only trabecular bone density in hypogonadal men, as our study showed [3,4,9-11].

A large number of clinical trials have demonstrated a positive effect of TRT on BMD. Most studies of TRT in hypogonadal men have been uncontrolled, relatively short-term, and involved small numbers of subjects with a variety of causes for their hypogonadism. Snyder et al. [12] showed that transdermal testosterone therapy increased spine BMD after 36 months of treatment (Testoderm, $6 \mathrm{mg}$ per 24 hour) but found no changes in femoral BMD. Wang et al. [13] studied BMD and bone turnover markers in 123 patients treated with long-term testosterone gel, including 27 patients with secondary hypogonadism due to pituitary tumors and hypothalamic tumors. They found a decrease in urine N-telopeptide in the first 6 months of treatment and a progressive and gradual increase in the BMD of the spine and hip. This increase in BMD was more marked in the spine than in the hip [13]. Our aim was to investigate BMD changes in postoperative pituitary tumor patients treated with TRT. Although many previous studies provided information on BMD levels only after 1 or 2 years of treatment, our study utilized a longer follow-up period of up to 99 months. However, our study has some limitations. First, many of our patients were receiving hormone replacement therapy with L-thyroxine and/ or hydrocortisone due to panhypopituitarism. Over replacement of these hormone agents is known to be harmful to the bone. We minimized the doses of L-thyroxine and hydrocortisone to achieve serum cortisol or free thyroxine levels within normal limits or slightly lower levels in all of cases. Second, a relatively small number of patients were analyzed in our study and the statistical power was relatively low. Third, serum testosterone levels increased during treatment but some patients still remained below the normal adult male range. Fourth, there are many factors associated with changes in BMD, such as diet, exercise, smoking, and alcohol. We were unable to collect these data from the medical chart review to include in our final analysis.

In conclusion, the present study suggests that TRT has a beneficial effect on BMD in postoperative hypogonadal patients with pituitary tumors.

\section{CONFLICTS OF INTEREST}

No potential conflict of interest relevant to this article was reported.

\section{REFERENCES}

1. Nieschlag E, Behre HM, Bouchard P, Corrales JJ, Jones TH, Stalla GK, Webb SM, Wu FC. Testosterone replacement therapy: current trends and future directions. Hum Reprod Update 2004;10:409-19.

2. Rudman D, Drinka PJ, Wilson CR, Mattson DE, Scherman F, Cuisinier MC, Schultz S. Relations of endogenous anabolic hormones and physical activity to bone mineral density and lean body mass in elderly men. Clin Endocrinol (Oxf) 1994;40:653-61.

3. Behre HM, Kliesch S, Leifke E, Link TM, Nieschlag E. Long-term effect of testosterone therapy on bone mineral density in hypogonadal men. J Clin Endocrinol Metab 1997; 82:2386-90.

4. Katznelson L, Finkelstein JS, Schoenfeld DA, Rosenthal DI, Anderson EJ, Klibanski A. Increase in bone density and lean body mass during testosterone administration in men with acquired hypogonadism. J Clin Endocrinol Metab 1996; 81:4358-65.

5. Okinaga H, Matsuno A, Okazaki R. High risk of osteopenia and bone derangement in postsurgical patients with craniopharyngiomas, pituitary adenomas and other parasellar lesions. Endocr J 2005;52:751-6.

6. Nieschlag E, Swerdloff R, Behre HM, Gooren LJ, Kaufman JM, Legros JJ, Lunenfeld B, Morley JE, Schulman C, Wang $\mathrm{C}$, Weidner W, Wu FC. Investigation, treatment, and monitoring of late-onset hypogonadism in males: ISA, ISSAM, and EAU recommendations. J Androl 2006;27:135-7.

7. Deb P, Gupta SK, Godbole MM. Effects of short-term testosterone replacement on areal bone mineral density and bone turnover in young hypogonadal males. Indian J Endocrinol Metab 2012;16:947-51.

8. Wang YJ, Zhan JK, Huang W, Wang Y, Liu Y, Wang S, Tan P, Tang ZY, Liu YS. Effects of low-dose testosterone undecanoate treatment on bone mineral density and bone turnover markers in elderly male osteoporosis with low serum testosterone. Int J Endocrinol 2013;2013:570413.

9. Vieira da Costa J, Pereira-Lima JF, da Costa Oliveira M. Bone mineral density in early-onset hypogonadism and the effect of hormonal replacement. J Clin Densitom 2004;7: 
334-40.

10. Choi HR, Lim SK, Lee MS. Site-specific effect of testosterone on bone mineral density in male hypogonadism. J Korean Med Sci 1995;10:431-5.

11. Wang C, Swerdloff RS, Iranmanesh A, Dobs A, Snyder PJ, Cunningham G, Matsumoto AM, Weber T, Berman N. Effects of transdermal testosterone gel on bone turnover markers and bone mineral density in hypogonadal men. Clin Endocrinol (Oxf) 2001;54:739-50.

12. Snyder PJ, Peachey H, Hannoush P, Berlin JA, Loh L,
Holmes JH, Dlewati A, Staley J, Santanna J, Kapoor SC, Attie MF, Haddad JG Jr, Strom BL. Effect of testosterone treatment on bone mineral density in men over 65 years of age. J Clin Endocrinol Metab 1999;84:1966-72.

13. Wang C, Cunningham G, Dobs A, Iranmanesh A, Matsumoto AM, Snyder PJ, Weber T, Berman N, Hull L, Swerdloff RS. Long-term testosterone gel (AndroGel) treatment maintains beneficial effects on sexual function and mood, lean and fat mass, and bone mineral density in hypogonadal men. J Clin Endocrinol Metab 2004;89:2085-98. 